\title{
Peningkatan pengetahuan remaja tentang bijak menggunakan media sosial di SMU Muhammadiyah Gombong
}

\section{Teenager's knowledge enhancement about how to use social media wisely on Muhammadiyah Gombong Senior High School}

\author{
Arizona Firdonsyah ${ }^{1 *}$, Zahra Arwananing Tyas ${ }^{2}$ \\ 1,2 Program Studi Teknologi Informasi, Universitas 'Aisyiyah Yogyakarta \\ Email: arizona@unisayogya.ac.id ${ }^{1}$, zahraatyas@unisayogya.ac.id ${ }^{2}$ \\ *Corresponding author: Arizona Firdonsyah
}

\begin{abstract}
ABSTRAK
Perkembangan media sosial dengan berbagai fitur yang dapat diakses di manapun membuat semakin banyak pengguna media sosial dari berbagai kalangan seperti remaja. Penggunaan media sosial dengan berbagai dampaknya perlu disosialisasikan kepada remaja karena saat ini media sosial memiliki dampak positif dan negatif. Kegiatan pengabdian terhadap masyarakat yang dilaksanakan di Sekolah Menengah Umum (SMU) Muhammadiyah Gombong, Kebumen berupa penyuluhan tentang dampak media sosial terutama terhadap remaja dan bagaimana menggunakannya dengan bijak. Pengabdian ini bertujuan untuk memberikan pemahaman mengenai dampak media sosial dan bagaimana para remaja dapat menggunakannya dengan bijak sehingga terhindar dari hal-hal yang bersifat negatif seperti tindakan asusila, penghinaan, pencemaran nama baik serta penyebaran berita bohong yang dianggap menyesatkan dan mengakibatkan adanya permusuhan antar individu dan atau kelompok masyarakat tertentu dilihat dari kelompoknya beradasarkan suku, agama, ras, dan antar golongan (SARA). Siswa yang sangat antusias dan bertambahnya pengetahuan serta kehati-hatian dalam penggunaan media sosial adalah hasil dari pengabdian masyarakat ini.
\end{abstract}

Kata Kunci: dampak; bijak; Media sosial; positif; remaja

\section{ABSTRACT}

The development of social media with various features that can be accessed anywhere causing the growth of social media users from various community, especially teenagers, is inevitable. The use of social media with its various impacts needs to be socialized to teenagers because currently social media has positive and negative impacts. Community service activities carried out at Muhammadiyah Gombong Senior High School, Kebumen in the form of counseling about the impact of social media and how to use it wisely. This service aims to provide an understanding of the impact of social media and how teenagers can use it wisely so as to avoid negative things such as immoral acts, insults, defamation and the spread of fake news that is considered misleading and results in hostility between individuals and groups. or certain community groups seen from their groups based on ethnicity, religion, race, and inter-group. Students who are very enthusiastic and increase in knowledge and caution in the use of social media are the result of this community service.

Keywords: social media; teenager; impact; wise; positive

\section{PENDAHULUAN}

Perkembangan teknologi semakin maju dan pesat, salah satunya dengan semakin banyaknya media sosial. Media sosial merupakan sekelompok aplikasi yang menggunakan basis internet serta penggunaan teknologi web yang di dalamnya terdapat penciptaan atau pertukaran informasi oleh penggunanya (Kaplan \& Haenlein, 2010). Lahirnya media sosial 
menjadikan pola perilaku masyarakat mengalami pergeseran baik budaya, etika, dan norma yang ada(Hager \& Wellein, 2021). Indonesia dengan jumlah penduduk yang besar dengan berbagai kultur suku, ras dan agama yang beraneka ragam memiliki banyak sekali potensi perubahan sosial.Media sosial yang banyak digunakan beberapa di antaranya adalah Facebook, Twitter, Whatsapp, Tik-tok, Instagram, Line, Brainly dan Google+. Media sosial ini memiliki banyak fitur yang digemari penggunanya seperti pemutakhiran linimasa, percakapan daring, unggah foto, dan pemutakhiran status.

Asosiasi Penyelenggara Jasa

Internet Indonesia (APJII)
memaparkan bahwa pada tahun 2019, Indonesia adalah pengguna media sosial aktif sebanyak 150 juta (naik $15 \%$ atau sekitar $20 \%$ dari tahun 2018) dan pengguna media sosial mobile sebanyak 130 juta (naik 8,3\% atau sekitar $10 \%$ dari tahun 2018). Peningkatan pengguna ini diikuti dengan meningkatnya kasus kejahatan siber melalui media sosial. Polri telah menangani sebanyak 5.061 kasus kejahatan siber pada tahun 2017. Angka kejahatan cyber naik 3\% disbanding pada 2016, yang berjumlah 4.931 kasus, dan lebih dari $50 \%$ kejahatan siber berasal dari media sosial terutama Facebook dan Twitter (Fitriani \& Pakpahan, 2020).

Perkembangan media sosial dengan berbagai fitur yang dapat diakses di manapun membuat semakin banyak pengguna media sosial dari berbagai kalangan. Jumlah pengguna media sosial aktif di Indonesia pada tahun 2015 tercatat sejumalh 79 juta orang. Jumlah tersebut meningkat secara signifikan menjadi 129,2 juta orang $(97,4 \%)$ pada tahun 2016 (Hestyana Sari et al., 2020).

Media sosial merupakan media bersifat online yang memfasilitasi interaksi antara penggunanya dengan cara pertukaran informasi, pendapat, dan peminatan. Media sosial terdiri dari beragam tools dan teknologi yang terdiri dari proyek gabungan, (contoh: Wikipedia, Wiki- spaces), blog (contoh: Wordpress), mikroblog (contoh: Twitter), konten komunitas (contoh: Youtube), situs jejaring sosial (contoh: Facebook, Instagram, Path), virtual game worlds (contoh: World of Warcraft), virtual social worlds (contoh: Second Life), dan semua akses berbasis internet lainnya. (Anwar, 2017)

Media sosial memiliki efek dalam komunikasi massa dan ilmu komunikasi. Kemajuan teknologi komunikasi dalam media sosial memunculkan masyarakat informasi. Masyarakat informasi ini membuat khalayak merasa memiliki kebebasan dalam berpartisipasi dalam ruang publik, serta bisa menjalin hubungan pertemanan (friendship, fanship). Pengguna media baru bebas melakukan aktivitas seperti membuat catatan, sirkulasi ulang konten media (Karman, 2014). 
Penggunaan Media Sosial yang semakin maju ini tentunya memberikan dampak di berbagai kalangan, terutama remaja dan pelajar. Media sosial menjadi trend bahkan sampai menjadi candu yang membuat para remaja tidak pernah melewatkan hari tanpa menggunakan media sosial. Pemakaian media sosial yang terus menerus ini, jika tidak diatur dengan bijak, dapat menimbulkan banyak dampak negatif seperti berkurangnya semangat dan capaian belajar siswa, perundungan, ujaran kebencian, penyebaran berita bohong, pencemaran nama baik, hingga pada level yang lebih besar seperti permusuhan antar komunitas atau kelompok masyarakat (Nurwita et al., 2020). Pengelolaan privasi dan identitas yang menjadi salah satu fitur pada media sosial juga berpotensi membuat para pemakainya dapat menampilkan karakter diri yang berbeda ketika berada di dunia maya dengan dunia nyata. Hal ini dapat menyebabkan semakin banyaknya identitas-identitas palsu yang menyebarkan berita-berita negatif (Reiza, 2019).

Pengabdian kepada masyarakat ini bertujuan untuk memberikan pemahaman mengenai penggunaan media sosial dengan bijak dan bagaimana menyikapi halhal negatif yang ditimbulkan media sosial sekaligus media promosi prodi ke SMU Muhammadiyah Gombong dan beberapa SMU/SMK sederajat lainnya. Hasil yang diharapkan dari pengabdian ini adalah siswa siswi
SMU Muhammadiyah Gombong dapat menambah wawasan intelektual dalam pembentukan karakter yang baik dan bijaksana terhadap pemakaian media sosial sehingga dapat dimanfaatkan untuk meningkatkan hal-hal yang bersifat positif seperti semangat dan capaian belajar siswa di sekolah dan dapat menghindari hal-hal yang bersifat negatif. Selain itu promosi dan branding prodi dapat tercapai melalui pengabdian ke SMU/SMK sederajat seperti yang dilakukan ini. Pengabdian masyarakat ini memberikan kontribusi terkait penambahan wawasan dan kehatihatian dalam penggunaan media sosial, khususnya di kalangan remaja

\section{METODE}

Program pengabdian kepada masyarakat ini berupa penyuluhan yang melibatkan 2 dosen pembimbing dan 2 orang mahasiswa. Kegiatan pengabdian masyarakat ini dilaksanakan pada tanggal 13 Januari 2021 dengan lokasi pelaksanaan kegiatan di SMU Muhammadiyah Gombong. Sasaran dari kegiatan pengabdian ini adalah para pelajar SMU Muhammadiyah Gombong, terutama siswa siswi kelas XII, namun tidak menutup kesempatan bagi siswa siswi kelas XI atau kelas X untuk ikut menjadi peserta dalam kegiatan pengabdian masyarakat ini.

Tahap-tahap yang dilakukan pada kegiatan pengabdian masyarakat ini terdiri dari: persiapan, pelaksanaan, penyusunan laporan, 
dan publikasi. Infografis terkait tahap-tahap pelaksanaan pengabdian ditunjukkan pada Gambar 1.

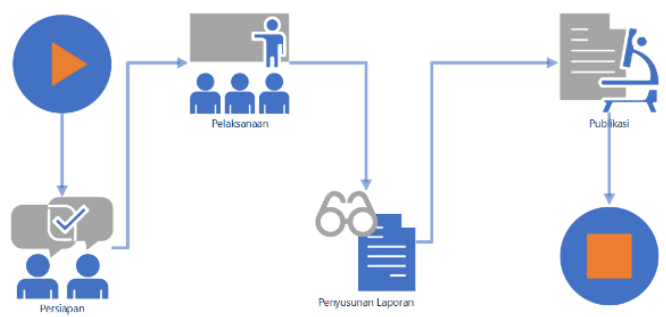

Gambar 1. Infografis Tahap-tahap pelaksanaan pengabdian masyarakat

Tahap persiapan merupakan kegiatan melakukan pengumpulan informasi dasar yang diperlukan terkait fokus materi dan sasaran kegiatan yang dilakukan secara daring dikarenakan masih dalam kondisi pandemi COVID-19 (Masi et al., 2020).

Tahap persiapan ini juga merupakan tahap inisiasi kerjasama dengan mitra. Inisiasi dilakukan dengan melakukan koordinasi melalui media aplikasi perpesanan instan dan teleconference sehingga tercapai kesepakatan terkait tanggal pelaksanaan kegiatan, proses surat menyurat, sasaran, dan teknis pelaksanaan.

Tahap pelaksanaan kegiatan terdiri dari beberapa sub tahapan yang meliputi: persiapan materi, pembekalan pemateri, dan pelaksanaan penyuluhan. Sub-sub tahapan ini dilakukan secara daring menggunakan aplikasi perpesanan instan yang memiliki fitur teleconference (Oktavianti \& Loisa, 2017). Pembekalan pemateri ini terutama terkait materi yang akan disampaikan dan teknik pelaksanaan penyuluhan kepada siswa siswi SMU Muhammadiyah Gombong.

Tahap penyusunan laporan dilakukan dengan cara merekapitulasi semua data dan hasil program yang berlangsung selama pelaksanaan kegiatan pengabdian masyarakat. Data dan hasil kegiatan ini meliputi: surat kerjasam dengan mitra, materi penyuluhan, daftar hadir peserta, dan dokumentasi kegiatan. Tahap ini juga merupakan tahap evaluasi untuk menentukan apakah pelaksanaan program tersebut sudah sesuai dengan target yang diharapkan atau tidak. Data-data yang didapatkan kemudian disusun menjadi sebuah laporan terstruktur dan sistematis.

Tahap selanjutnya adalah tahap publikasi. Tahap publikasi merupakan tahap penyusunan laporan kegiatan menjadi sebuah rangkuman artikel ilmiah. Artikel ilmiah ini kemudian dipublikasikan melalui jurnal maupun seminar.

\section{HASIL DAN PEMBAHASAN}

Kegiatan pengabdian masyarakat di SMU Muhammadiyah Gombong ini melibatkan dua orang mahasiswa yang berasal dari Program Studi Teknologi Informasi, Fakultas Sains dan Teknologi, Universitas 'Aisyiyah Yogyakarta.

Kegiatan pengabdian masyarakat dimulai dengan tahap pemilihan fokus sasaran kegiatan dan koordinasi dengan mitra. Pengabdian masyarakat dilaksanakan dengan 
tetap memperhatikan situasi dan kondisi yang sedang terjadi saat ini yaitu pandemi Covid-19, sehingga semua proses dilaksanakan secara daring seperti ditunjukkan pada Gambar 2.
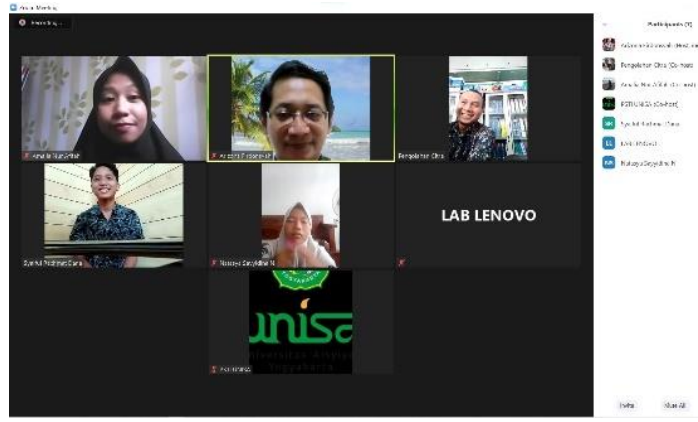

Gambar 2. Persiapan Penyuluhan Daring melalui Zoom Cloud Meeting

Tahap pelaksanaan kegiatan dimulai dengan memberikan penyuluhan secara daring kepada peserta melalui aplikasi zoom cloud meeting. Penyuluhan ini dilakukan langkah-langkah sebagai berikut:

1. Pembukaan sekaligus dengan perkenalan

2. Presentasi atau pemaparan dengan memaparkan materi yang terkait dengan penyuluhan tersebut.

3. Sesi tanya jawab, di mana para peserta (siswa dan para guru) bertanya mengenai apa pentingnya UU ITE khususnya dalam penggunaan dari media sosial yang baik di kalangan siswa sekolah maupun masyarakat luas pada umumnya. (Novita Eleanora \& Sari, 2020)

Antusiasme peserta pada saat pelaksanaan kegiatan terlihat sangat tinggi. Peserta yang terdiri dari siswa siswi SMU tentunya sangat mengenal dan merupakan pengguna aktif media sosial seperti tiktok, instagram, facebook, dan lain sebagainya.

Peserta diperkenalkan pada definisi media sosial dan statistik pengguna media sosial, disertai dengan penjelasan konten-konten di media sosial yang disampaikan secara interaktif melalui ilustrasi gambar dan infografis yang sistematis seperti ditunjukkan pada Gambar 3 dan 4, dipadukan dengan penjelasan yang menarik dari pemateri.

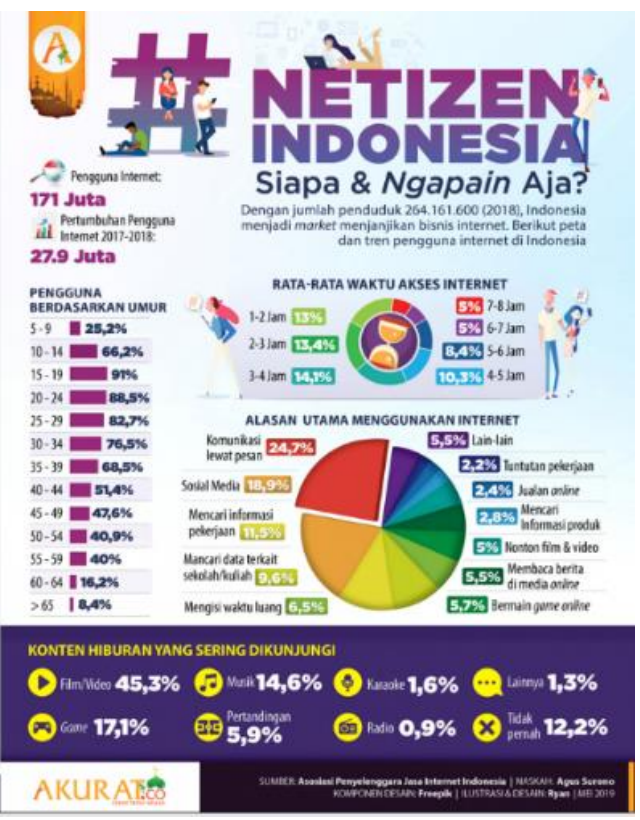

Gambar 3. Contoh infografis terkait jumlah pengguna media social

Peserta juga diberikan pemahaman terkait kasus-kasus terkini yang terjadi akibat penggunaan media sosial yang tidak bijak. Penyuluhan diakhiri dengan penjelasan bagaimana penggunaan sosial media yang bijak diikuti diskusi interaktif dan sesi tanya jawab yang diikuti peserta dengan tingkat 
keaktifan tinggi seperti ditunjukkan pada Gambar 5 dan 6.

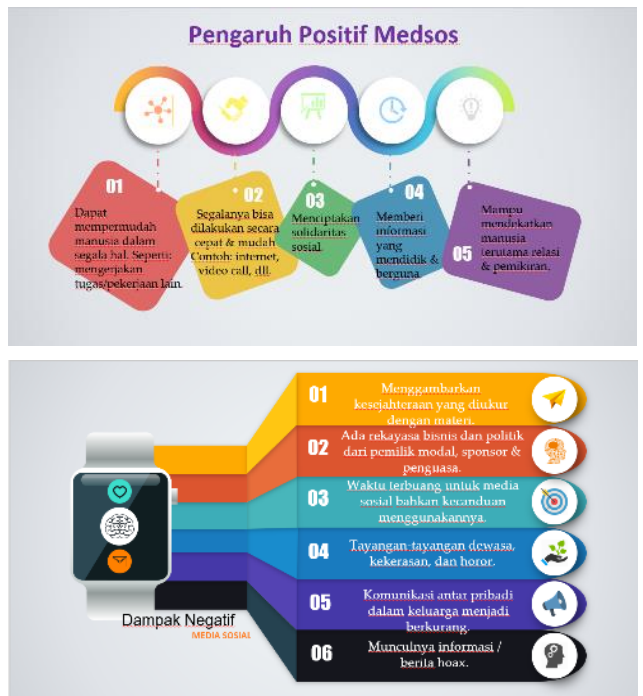

Gambar 4. Contoh infografis terkait dampak positif dan negatif media sosial

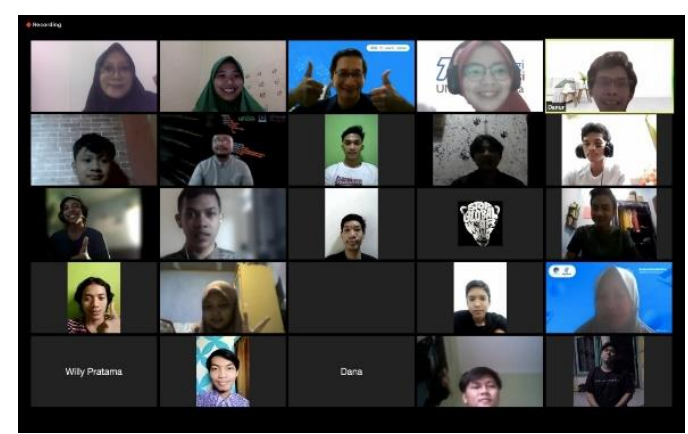

Gambar 5. Sesi tanya jawab

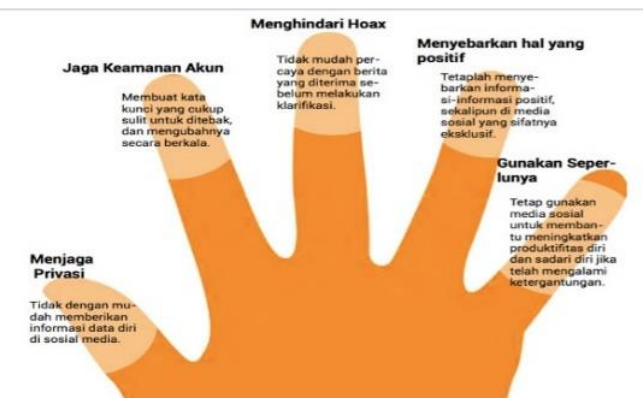

Gambar 6. Contoh infografis terkait cara menggunakan media sosial dengan bijak

\section{KESIMPULAN}

Generasi muda, dalam hal ini siswa SMU, memiliki akses yang tinggi terhadap media sosial. Siswa siswi SMU terkadang belum mampu memilah informasi atau berita di media sosial dan mengidentifikasi sumber yang kredibel dari berbagai sumber yang muncul di media sosial sehingga rentan kemungkinan terpapar atau mendapatkan hal-hal yang negatif.

Dampak buruk atau hal-hal yang negatif pada media sosial dapat dicegah dengan edukasi yang tepat. Pengabdian kepada masyarakat ini dalam rangka pencegahan dampak buruk pemakaian media sosial terhadap remaja.

Pengabdian masyarakat ini berhasil menambah wawasan intelektual dalam pembentukan karakter yang baik dan bijaksana terhadap pemakaian media sosial sehingga dapat di manfaatkan untuk hal-hal yang positif seperti menambah wawasan pembelajaran, meningkatkan prestasi akademis, dan menghindarkan diri dari hal-hal yang negatif yang ada pada media sosial.

\section{UCAPAN TERIMAKASIH}

Ucapan terimakasih diberikan kepada Universitas 'Aisyiyah Yogyakarta yang melalui Lembaga Penelitian dan Pengabdian Kepada Masyarakat (LPPM) telah membiayai pelaksanaan kegiatan pengabdian kepada masyarakat ini sehingga dapat berjalan sesuai dengan program yang telah ditetapkan. Ucapan terimakasih 
juga diberikan kepada SMU

Muhammadiyah Gombong, atas kerjasama dan kesediaannya dalam kegiatan pengabdian masyarakat ini.

\section{DAFTAR PUSTAKA}

Anwar, F. (2017). Perubahan dan Permasalahan Media Sosial. Jurnal Muara Ilmu Sosial, Humaniora, Dan Seni, 1(1), 137. https://doi.org/10.24912/jmishu msen.v1i1.343

Fitriani, Y., \& Pakpahan, R. (2020). Analisa Penyalahgunaan Media Sosial untuk Penyebaran Cybercrime di Dunia Maya atau Cyberspace. CAKRAWALA: Jurnal Humaniora Bina Sarana Informatika, 20(1).

Hager, G., \& Wellein, G. (2021). Pengaruh Media Sosial Terhadap Perubahan Sosial Masyarakat Di Indonesia. Introduction to High Performance Computing for Scientists and Engineers, 194210.

https://doi.org/10.1201/ebk1439 811924-14

Hestyana Sari, T., Delvira, W., Wirdaniza, D., \& Salshabella Ashali, S. (2020). Peningkatan Pengetahuan Remaja Tentang Dampak Positif Dan Negatif Penggunaan Media Sosial Terhadap Kesehatan Fisik Dan Mental Dengan Pendekatan Peer Group Di Smpn 21 Pekanbaru. Jurnal Pengabdian Masyarakat Multidisiplin, 4(1), 56-67. http://dx.doi.org/10.1016/j.ndtei nt.2014.07.001\%0Ahttps://doi.o rg/10.1016/j.ndteint.2017.12.00 3\%0Ahttp://dx.doi.org/10.1016/ j.matdes.2017.02.024

Kaplan, A. M., \& Haenlein, M. (2010). Users of the world, unite! The challenges and opportunities of Social Media. Business Horizons, 53(1), 5968.

https://doi.org/10.1016/j.bushor. 2009.09.003

Karman. (2014). Media Sosial: Antara Kebebasan Dan Eksploitasi Social Media : Between Freedom and Exploitation. Jurnal Studi Komunikasi Dan Media, 18(1), 75-88.

Masi, L., Sudia, M., Salim, S., Prajono, R., \& Sarina, S. (2020). Pemanfaatan Media Sosial Sebagai Sarana Komunikasi dalam Pencegahan Meluasnya Wabah COVID-19 di Kalangan Pelajar. Humanism: Jurnal Pengabdian Masyarakat, 1(3), 219-228.

https://doi.org/10.30651/hm.v1i 3.5754

Novita Eleanora, F., \& Sari, A. (2020). Penyuluhan Pengaruh Media Sosial Di Kalangan Pelajar Sekolah Menengah Atas Cenderawasih 1 Jakarta. 3(3), 216-221.

Nurwita, N., Susanti, F., Permada, D. N. R., Oktrima, B., \& Irawati, L. (2020). Dampak Buruk Pemakaian Media Sosial Terhadap Semangat Dan Capaian Belajar Siswa Smp Arraisiyah Pamulang". Jurnal ABDIMAS Tri Dharma Manajemen, $\quad 1(1), \quad 66$. https://doi.org/10.32493/abmas. v1i1.p66-76.y2019

Oktavianti, R., \& Loisa, R. (2017). Penggunaan Media Sosial Sesuai Nilai Luhur Budaya di Kalangan Siswa SMA. Jurnal Pengabdian Kepada Masyarakat (Indonesian 
Arizona Firdonsyah, Zahra Arwananing Tyas/ Jurnal Hayina "Hasil Karya Aisyiyah Untuk Indonesia". Vol. 1, No. 1 Oktober 2021 Hal $38-45$

Journal of Community Engagement), $3(1), \quad 86$. https://doi.org/10.22146/jpkm.2 6925

Reiza, A. D. (2019). Optimalisasi Penggunaan Media Sosial Bagi Kalangan Remaja di SMA Negeri 1 Panga Aceh Barat. Jurnal Pengabdian Masyarakat: Darma Bakti Teuku Umar, 1(1), 74.

https://doi.org/10.35308/baktiku .v1i1.1283 